\title{
MOGIGU (MENGGOSOK GIGI ASYIK DENGAN LAGU) TO INCREASE BRUSHING TEETH OF THE ELEMENTARY SCHOOL
}

\author{
Diyah Fatmasari' $^{1)}$, Rasipin ${ }^{2)}$, Bedjo Santoso ${ }^{3)}$, Supriyana ${ }^{4)}$, Wahyu Jati Dyah Utami ${ }^{\text {) }}$ \\ Email : fatmasaridiyah@gmail.com
}

\begin{abstract}
Tooth brushing programs that have been carried out in schools have not been able to change the brushing behavior of elementary school students, shown by OHI-S value $=1.3$; DMF-T=1.09, def- $t=1.78$. Program improvement in behavioral aspects needs to be done to improve the dental health level of elementary school students. Behavioral changes are influenced by information. Information will be stored as much as $20 \%$ if delivered through visuals, $50 \%$ of the cost is delivered through audiovisual media and $70 \%$ if implemented in real practice.

Analyze the effectiveness of the audiovisual media model on tooth brushing habits of schoolchildren

Method is Quasy experiment with pretest and posttest with control group design. The sample was divided into 2 groups, the audiovisual model in the intervention group, and the brushing program in the control group. The treatment was carried out for 21 days, the measurements were carried out pre-experiment, 25th and 35th days. Data were tested using the test freedman post hoc Wilcoxon, Man Whitney repeated, and Kruskal.

On the 25th-day measurement of significant changes in variable ways, long brushing teeth $\mathrm{p}<0.05$. At the 35 th day measurement, there was a significant change in the method variable, morning brushing teeth $\mathrm{p}<0.05$. This model is effective against the formation of the habit of brushing teeth indicated by $\mathrm{p}<0.001$.

Mogigu model's has the potential as an alternative to brush your teeth together in school so that it can be applied in the School Dental Health Business.
\end{abstract}

Keywords: Brushing teeth, Primary School students, Audiovisual

1) Poltekkes Kemenkes Semarang

\section{PENDAHULUAN}

Kesehatan gigi dan mulut merupakan bagian tak terpisahkan dari kesehatan secara umum, seseorang yang mengalami masalah kesehatan gigi dan mulut akan berpengaruh terhadap kesehatan secara umum, artinya penyakit gigi dan mulut dapat menjadi faktor risiko penyakit lain. ${ }^{(1,2)}$ Lebih dari 50 juta jam sekolah pertahun hilang karena penyakit gigi dan mulut, yang akan berdampak pada penampilan anak-anak di sekolah dan kesuksesan hidupnya kelak. ${ }^{(3)}$ Riset Kesehatan Dasar (Indonesia Basic Health Research) tahun 2013 menunjukkan bahwa 91, 1\% penduduk Indonesia umur 10 tahun keatas mempunyai kebiasaan menggosok gigi setiap hari, namun hanya $7,3 \%$ yang telah menggosok gigi secara benar, yaitu pagi setelah sarapan dan malam sebelum tidur. (4) Orang Indonesia menggosok gigi dilakukan rata rata dalam 1.27 kali per hari. Rerata waktu lamanya menggosok gigi adalah 57.29 detik. ${ }^{(5)}$

Usaha untuk mengatasi masalah kesehatan gigi pada anak sekolah yang sudah berjalan yaitu program Usaha Kesehatan Gigi Sekolah 
(UKGS). Usaha kesehatan gigi sekolah memberikan pelayanan dalam bentuk promotif, preventif, kuratif dan rehabilitatif yang ditujukan bagi anak usia sekolah. Aspek promotif yang dilakukan dalam UKGS di sekolah adalah kegiatan menggosok gigi bersama $^{(6)}$. Program menggosok gigi bersama ini sangat penting untuk diberikan kepada siswa sekolah dasar karena menggosok gigi merupakan usaha pelihara diri yang paling dasar yang bisa menentukan kesehatan gigi anak sampai dewasa nanti. Program menggosok gigi bersama mendapat dukungan secara International oleh Federation Dentaire Internationale (FDI), World Health Organisation (WHO), dan International Association for Dental Research (IADR) melalui Global Oral Health Programme (GOHP) serta revolusi sidang World Health Assembly (WHA) ke-60 tahun 2007 mengembangkan dan mengimplementasikan promosi kesehatan gigi dan mulut serta pencegahan penyakit gigi dan mulut sebagai bagian dari kegiatan promosi kesehatan dengan fokus pada Perilaku Hidup Bersih dan Sehat (PHBS) dan praktik perawatan diri sendiri di sekolah, yaitu dengan pelaksanaan menggosok gigi setiap hari di sekolah ${ }^{(7,8)}$

Program menggosok gigi di Sekolah Dasar Kota Semarang belum rutin dilaksanakan, rata rata dilakukan dalam 1 tahun sekali bersaman dengan Program UKGS . ${ }^{(9)}$ Hasil studi pendahuluan di SD Padangsari 1 Banyumanik 95\% siswa memiliki keterampilan menggosok gigi saat mandi, $90 \%$ siswa tidak terampil dalam menggosok gigi, rata rata nilai $\mathrm{OHI}-\mathrm{S}=1,3$; DMF-T $=1.09$, def- $\mathrm{t}=1,78$, kondisi tersebut belum memenuhi target nasional 2010 yaitu $\mathrm{DMF}-\mathrm{T} \leq 2$, def-t $<2, \quad$ OHI-S $\leq 1,2 \quad$. $^{(10)}$ Berdasarkan data tersebut program menggosok gigi yang selama ini sudah dijalankan di sekolah belum mampu mengubah perilaku menggosok gigi siswa sekolah dasar menjadi lebih baik dan benar.
Perbaikan perlu dilakukan pada keterampilan menggosok gigiuntuk meningkatkan derajat kesehatan gigi siswa sekolah dasar, dimana derajat kesehatan dipengaruhi oleh lingkungan, pelayanan kesehatan, keturunan, dan perilaku. ${ }^{(11)}$ Faktor perilaku yang secara teoritis memiliki andil 30-35 \% terhadap derajat kesehatan. ${ }^{(12)}$ Mengingat dampak perilaku terhadap derajat kesehatan cukup besar, maka diperlukan berbagai upaya untuk mengubah perilaku menggosok gigi siswa sekolah dasar. Berdasarkan permasalahan tersebut diatas perlu dilakukan penelitian dalam upaya mengubah pola perilaku dalam keterampilan menggosok gigi siswa sekolah dasar sehingga dimungkinkannya dihasilkannya inovasi sebagai alternatif program menggosok gigi

\section{METODE PENELITIAN}

Desain penelitian quasy experiment dengan pretest and posttest with control group design non Randomized Control Group Pretest and Posttest Design ( Non Equivalent Control Group). Sampel dibagi menjadi 2 kelompok, mogigu model pada kelompok intervensi, dan program menggosok gigi pada kelompok kontrol. Pemberian perlakuan dilaksanakan selama 21 hari, pengukuran dilaksanakan preekperiment, hari ke-25 dan hari ke-35. Data diuji menggunakan uji man whitney berulang, dan Kruskall Wallis. Populasi siswa Sekolah Dasar SD Padangsari 1 Kecamatan Banyumanik Kota Semarang. SD Padangsari 1 dijadikan populasi dalam penelitian ini karena berdasarkan laporan data UKGS di Puskesmas Padangsari SD ini memiliki rata rata score $\mathrm{DMF}-\mathrm{T} \leq 2$, def-t $<2$, OHI-S $\leq 1,2$, dibawah target nasional tahun 2010. Sampel dibagi menjadi 2 kelompok, mogigu model pada kelompok intervensi, dan program menggosok gigi pada kelompok kontrol. Teknik pengambilan sampel yang digunakan peneliti adalah purposive sampling. Perkiraan besar 
sampel pada penelitian ini menggunakan perhitungan besar sampel minimal dapat menggunakan rumus besar sampel uji hipotesis terhadap rerata dua populasi independen (Lemeshow et al.,1990;Sastroasmoro dkk, 2010) $)^{(13)}$, didapatkan nilai 60, dengan pembagian 30 pada kelompok intervensi dan 30 kelompok control.

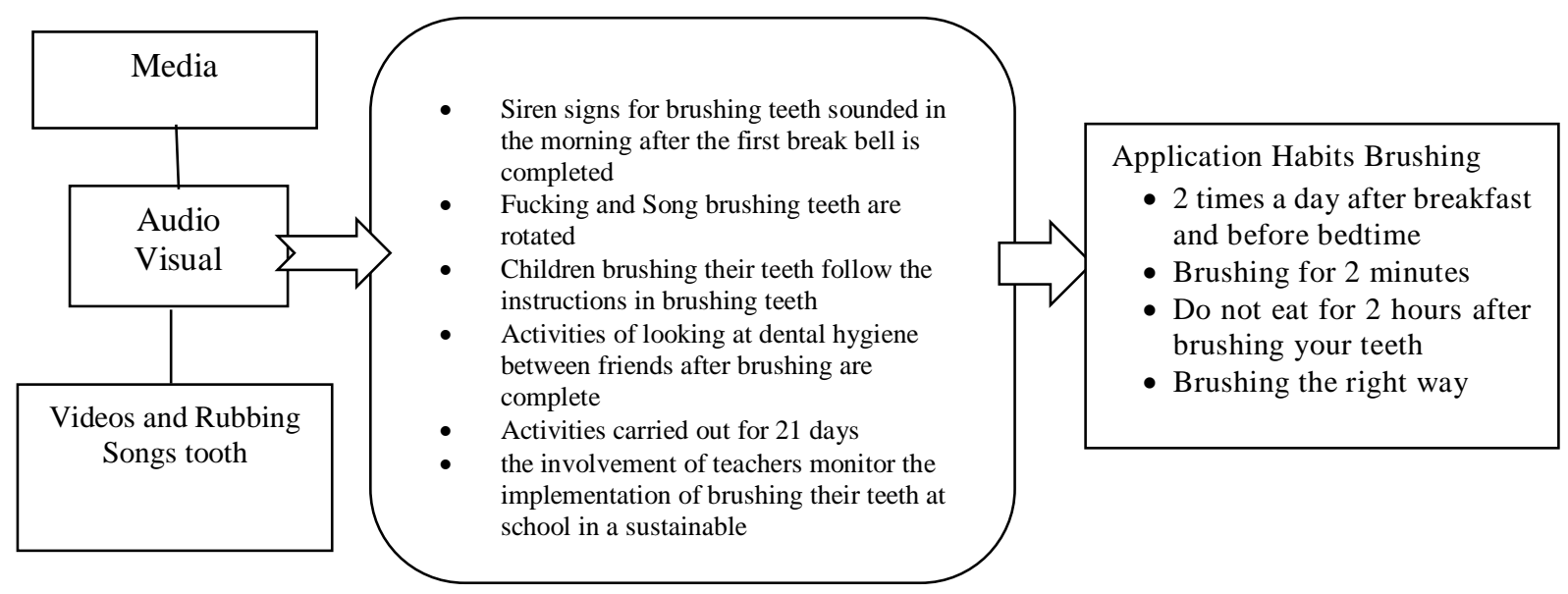

Gambar 1 Mogigu Model's dalam meningkatkan keterampilan Menggosok Gigi Siswa Sekolah Dasar

\section{HASIL DAN PEMBAHASAN}

Untuk menganalisis efektifitas mogigu models terhadap keterampilan menggosok gigi siswa Sekolah Dasar maka dilakukan pengujian statistic. Hasil uji normalitas data sebagai berikut :

Tabel 1. Uji normalitas data kelompok intervensi dan kelompok kontrol sebelum intervensi $(\mathbf{n}=60)$

\begin{tabular}{ll}
\hline No $\quad$ Variabel & Signifikansi \\
\hline 1. Lama pre test & 0.00 \\
2. Lama post test 1 & 0.00 \\
3. Lama post test 2 & 0.00 \\
4. Cara pre test & 0.01 \\
5. Cara post test 1 & 0.00 \\
6. Cara post test 2 & 0.00 \\
\hline
\end{tabular}

Berdasarkan uji normalitas diperoleh distribusi data tidak normal $\mathrm{p}>0,05$. Karena data tidak berdistribusi tidak normal maka akan dilanjutkan dengan uji Man Whitney, hasil uji Man Whitney sebagai berikut :
Tabel 2 Keterampilan Menggosok Gigi sebelum dan setelah intervensi model mogigu $(\mathbf{n}=60)$

\begin{tabular}{|c|c|c|c|}
\hline Variabel & $\begin{array}{c}\begin{array}{c}\text { Interve } \\
\text { nsi }\end{array} \\
\text { Mean } \\
\text { Rank }\end{array}$ & $\begin{array}{c}\begin{array}{c}\text { Kontr } \\
\text { ol }\end{array} \\
\text { Mean } \\
\text { Rank }\end{array}$ & $\mathrm{Z} \pm p$-value \\
\hline $\begin{array}{l}\text { Cara } \\
\text { Menggosok } \\
\text { Gigi }\end{array}$ & & & \\
\hline a. Pre test & 31.70 & 29.30 & $\begin{array}{l}- \\
554 \pm 0.580 \\
*\end{array}$ \\
\hline b. Post test 1 & 35.08 & 25.92 & $\begin{array}{l}- \\
2.138 \pm 0.03 \\
3 *\end{array}$ \\
\hline c. Post test 2 & 34.90 & 26.10 & $\begin{array}{l}- \\
2.098 \pm 0.03 \\
6^{*}\end{array}$ \\
\hline
\end{tabular}

*Uji Man Whitney

Berdasarkan hasil penelitian ini, dapat diketahui nilai rata rata cara menggosok gigi mengalami peningkatan antara sebelum dan 18 | Page 
setelah intervensi pada kelompok perlakuan. Hasil uji statistik menunjukan ada perbedaan cara menggosok gigi setelah 25 hari intervensi $(p=0.033, \quad p<0.05)$ dan sesudah 35 hari intervensi $(p=0.036, p<0.05)$.

Gambar 2. Grafik Interaksi nilai rata rata cara menggosok gigi diantara waktu dan diantara kelompok

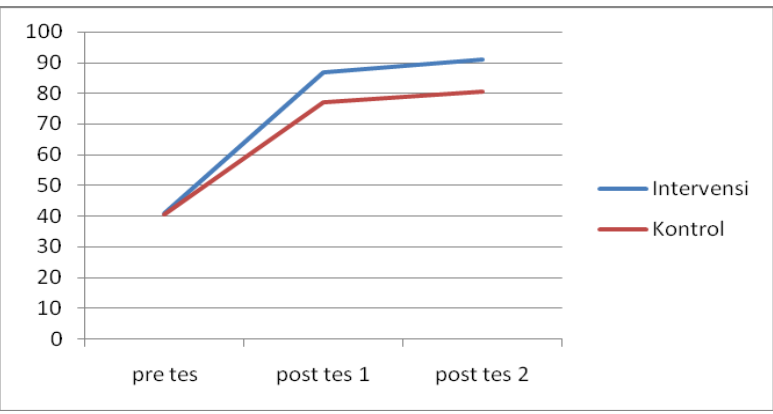

Dari grafik diatas dapat dilihat cara menggosok gigi kelompok mogigu model lebih unggul baik pada pengukuran hari ke-25 maupun ke-35.

Lama menggosok gigi siswa sekolah dasar sebelum dan sesudah intervensi mogigu modelsmenggosok gigi didapatkan hasil sebagai berikut:

Tabel 3. Lama Menggosok Gigi sebelum dan setelah intervensi model mogigu( $(n=60)$
Dari tabel 3 menunjukan jumlah siswa menggosok gigi lebih dari 2 menit mengalami peningkatan antara sebelum dan setelah intervensi pada kelompok perlakuan. Hasil uji statistik menunjukan terdapat perbedaan lama menggosok gigi setelah 25 hari intervensi $(p=0.034, \quad p<0.05)$ dan sesudah 35 hari intervensi $(p=0.0024, \mathrm{p}<0.05)$.

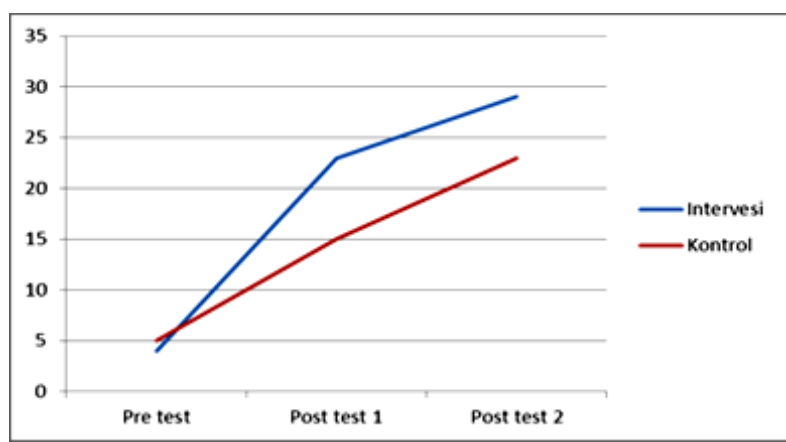

Gambar 3 Grafik Interaksi nilai rata rata lama menggosok gigi diantara waktu dan diantara

$$
\text { kelompok }
$$

Dari grafik diatas dapat dilihat lama menggosok gigi selama 2 s.d 3 menit, kelompok mogigu model lebih unggul pada pengukuran hari ke-25 maupun ke-35.

Efektivitas mogigu models terhadap keterampilan menggosok gigi siswa sekolah

\begin{tabular}{cccc} 
Variabel & $\begin{array}{l}\text { Interve } \\
\text { nsi }\end{array}$ & $\begin{array}{l}\text { Kontr } \\
\text { ol }\end{array}$ & $\mathrm{Z} \pm p$-value \\
& Mean & Mean & \\
Rank & Rank & \\
\hline
\end{tabular}

\section{Lama}

Menggosok

Gigi

\begin{tabular}{|c|c|c|c|}
\hline a. Pre test & 30.00 & 31.00 & $\begin{array}{l}- \\
0.359 \pm 0.72 \\
0 *\end{array}$ \\
\hline b. Post test 1 & 34.50 & 26.50 & $\begin{array}{l}- \\
2.125 \pm 0.03 \\
4 *\end{array}$ \\
\hline c. Post test 2 & 33.00 & 28.00 & $\begin{array}{l}- \\
1793 \pm 0.02 \\
4 *\end{array}$ \\
\hline
\end{tabular}

*Uji Man Whitney dasar dengan menggunakan uji Kruskall Wallis.

Tabel 4. Efektifitas Mogigu
modelsTerhadap Keterampilan menggosok gigi Gigi

$\begin{array}{cccc}\text { Variabel } & \begin{array}{c}\text { Interven } \\ \text { si }\end{array} & \begin{array}{c}\text { Kontr } \\ \text { ol }\end{array} & \begin{array}{c}\text { Interven } \\ \text { i-kontrol } \\ \text { Mean }\end{array} \\ & \text { Rank } & \begin{array}{c}\text { Mean } \\ \text { Rank }\end{array} & \\ & & \text { Ralue } \\ & & \end{array}$

\begin{tabular}{lll}
\hline Lama & 33.00 & 28.00
\end{tabular}

Menggosok

Gigi

Cara

$32.50 \quad 28.50$

0.000
Menggosok

Gigi

*Uji Kruskall Wallis 
Tabel 4 hasil analisis dengan uji Kruskal Wallis diatas didapatkan nilai $\mathrm{p}<0.001$, sehingga dapat disimpulkan bahwa mogigu modelsefektif terhadap keterampilan menggosok gigisiswa sekolah dasar. Variabel keterampilan menggosok gigimeliputi lama menggosok gigi, dan cara menggosok gigi antara kelompok intervensi dan kontrol, $\mathrm{p}<0.001$

Berdasarkan hasil uji efektivitas mogigu modelsterhadap keterampilan menggosok gigididapatkan perubahan bermakna $(\mathrm{p}<0.05)$, hal ini menunjukan mogigu modelsefektif terhadap keterampilan menggosok gigi gigi. Efektivitas mogigu model ini dikarenakan model ini menggunakan media yang melibatkan audio, dan visual. Dimana Audio melibatkan telinga sedangkan visual melibatkan mata sebagai pancaindera. ${ }^{(14)}$ Pada saat menggosok gigi siswa sekolah dasar melihat dan mendengar langsung instruksi yang diberikan, sehingga informasi yang didapat akan lebih mudah diterima. Semakin banyak pancaindra yang dirangsang maka masukan informasi akan semakin mudah. Hal ini sesuai yang dikemukakan Notoatmodjo, pancaindera yang banyak menyalurkan pengetahuan ke otak adalah mata (sekitar $75 \%$ sampai $87 \%$ ), sedangkan $13 \%$ sampai $25 \%$ pengetahuan manusia diperoleh dan disalurkan melalui pancaindra yang lain. ${ }^{(15)}$ Faktor lain yang mempengaruhi efektifitas model ini diduga karena mogigu model's dilaksanakan dengan praktek menggosok gigi secara konstan selama 21 hari. Kegiatan menggosok gigi yang dilakukan secara berulang ulang oleh siswa sekolah dasar menjadikan siswa terbiasa dalam melakukan, dengan praktek langsung siswa akan lebih mudah mengaplikasikan pesan yang disampaikan. Dalam teori Notoadmojo informasi akan tersimpan sebanyak $20 \%$ jika disampaikan melalui visual, $50 \%$ bia disampaikan melalui media audiovisual dan 70 $\%$ bila dilaksanakan dalam praktek nyata (Notoadmojo, 2012). ${ }^{(16)}$ Praktek menggosok gigi dilaksanakan selama 21 hari dikarenakan menurut teori (Foster dalam Maher dkk, 2014) selama 21 hari untuk mengubah kebiasaan seseorang maka diperlukan satu periode yang konstan dikondisikan kepada orang tersebut agar mengubah kebiasaanya. ${ }^{(17)}$ Informasi yang disampaikan melalui media audio visual dan praktek. Menjadikan pengetahuan siswa sekolah dasar menjadi meningkat. Hasil pengetahuan yang didapatkan dari pemberian media yang diberikan, akan menimbulkan sikap yang baik, dan akhirnya memunculkan tindakan menggosok gigi, hal ini sejalan dengan. Teori Preceed Proceed mengemukakan bahwa pengetahuan dan sikap merupakan faktor predisposisi perubahan perilaku kesehatan. ${ }^{(18)}$ Setelah seseorang mengetahui stimulus, kemudian mengadakan penilaian atau sikap, proses selanjutnya adalah ia akan mempraktikkan apa yang diketahuinya dengan mempertimbangkan informasi dan keyakinan tentang keuntungan dan kerugian yang didapat. ${ }^{(19)}$

Cara menggosok gigi pada kelompok intervensi lebih baik dibandingkan kelompok kontrol dibuktikan dengan hasil uji Man Whitney kelompok tidak berpasangan diperoleh nilai $p<0.05$. Hal tersebut menunjukan adanya suatu faktor yang berpengaruh terhadap perbedaan cara menggosok gigi diantara kedua kelompok. Faktor yang paling berpengaruh adalah perbedaaan perlakuan yang diterima pada kedua kelompok. ${ }^{(20)}$ Hal ini terjadi disebabkan pelatihan menggosok gigi dengan mogigu modelsmemiliki beberapa kelebihan. Media audio visual menggunakan lagu yang diiringi musik. Warna musik dapat meningkatkan daya ingat, medengarkan musik juga bisa meningkatkan motivasi dan membuat seseorang lebih bersemangat ${ }^{(21)}$.

Siswa yang memperoleh mogigu modelslebih banyak yang melakukan meggosok gigi dengan lama menggosok gigi rata rata 2 s.d 3 menit. Hal ini menunjukan 
mogigu modelsmenjadikan siswa menggosok gigi selama 2 s.d 3 menit. Waktu yang efektif untuk menggosok gigi yaitu selama 2 s.d menit $^{(22)}$. Mogigu modelsmenggunakan lagu yang digunakan untuk mengukur waktu dalam menggosok gigi. Lagu menggosok gigi berdurasi selama 2 s.d 3 menit. Musik dari audio yang dihasilkan dapat merangsang meremajakan dan memperkuat belajar baik secara sadar maupun tidak sadar. Irama, ketukan dan keharmonisan musik mempengaruhi fisiologi manusia terutama gelombang otak dan detak jantung. ${ }^{(23)}$ Musik membuat siswa secara sadar maupun tidak sadar untuk melakukan tindakan menggosok gigi, selain itu media audio juga memiliki keunggulan dapat merangkum, mengemukakan kembali, maupun mengingat kembali informasi yang telah diberikan sebelumnya (24). Dengan kelebihan yang dimiliki mogigu model mengkondisikan siswa secara sadar maupun tidak sadar untuk menggosok gigi selama 2 s.d 3 menit.

\section{SIMPULAN DAN SARAN}

Mogigu model terbukti efektif dalam meningkatkan keterampilan menggosok gigi Siswa Sekolah Dasar. Terbukti bahwa unsur audio visual yang ada dalam mogigu models, merangsang indera pendengaran dan penglihatan dalam menyerap Informasi, dan praktek menggosok gigi selama 21 hari membentuk memori dan memerintah tubuh melakukan suatu kebiasaan, sehingga terjadi peningkatan pengetahuan, terbentuk sikap yang baik, dan memunculkan perubahan perilaku dalam keterampilan menggosok gigisiswa sekolah dasar. Model ini dapat digunakan sebagai alternatif dari model menggosok gigi bersama di sekolah yang selama ini dilakukan

\section{DAFTAR PUSTAKA}

1. Sheiham A. Oral health, general health and quality of life. Bulletin of the World Health Organization. 2005;83(9):644-.

2. Arifah S. Pengaruh Pendidikan Kesehatan dengan Modul dan Media Visual Terhadap Peningkatan Pengetahuan dan Sikap Wanita Dalam Menghadapi Menopause (Studi Eksperimen Pada Wanita Premenopause di Desa Sumber Mulyo). Publikasi Penelitian. 2010.

3. Sriyono NW. Pencegahan penyakit gigi dan mulut guna meningkatkan kualitas hidup. text. 2009.

4. Indonesia KKR. Riset kesehatan dasar 2013. Jakarta: Badan Penelitian dan Pengembangan Kesehatan RI. 2013.

5. Rahardjo A, Maharani DA, Kiswanjaya B, Idrus E, Nicholson J, Cunningham P, et al. Measurement of tooth brushing frequency, time of Day and duration of adults and children in Jakarta, Indonesia. Journal of Dentistry Indonesia. 2015;21(3):85-8.

6. Indonesia KKR. Pedoman Usaha Kesehatan Gigi Sekolah (UKGS). Jakarta, Direktorat Jenderal Bina Upaya Kesehatan; 2012.

7. Hobdell M, Petersen PE, Clarkson J, Johnson N. Global goals for oral health 2020. International dental journal. 2003;53(5):285-8.

8. Petersen PE. World Health Organization global policy for improvement of oral health-World Health Assembly 2007. International dental journal. 2008;58(3):115-21.

9. Santoso B T, Nyoman Gejir, Diyah Fatmasari. Information System Monitoring Model Implemented in School Health Dental Unit. ARC Journal of Dental Science. 2017;2(4):8-11.

10. Purnomowati RRD. Efektivitas Sikat Gigi Orthodontik Dan Sikat Gigi Konvensional Terhadap Nilai Ohi-S Pada Pasien Fixed Orthodontic Appliance. Jurnal Keperawatan. 2018;13(1):53-7. 
11. Keman S. Kesehatan perumahan dan lingkungan pemukiman. Jurnal Kesehatan Lingkungan. 2005;2(1).

12. Dharmawan Y. Dasar Penelitian Kesehatan.

13. Sastroasmoro S, Penelitian ISD-DM. Klinis, edisi ke-3. Jakarta: CV Sagung Seto. 2008

14. Yulfitria F. Pengaruh Pendidikan Kesehatan dalam Meningkatkan Pengetahuan Tentang Pencegahan Keputihan Patologi. Jurnal Bidan. 2017;3(2):73-82.

15. Silaban PJ. Meningkatkan Motivasi dan Kemampuan Pemahaman Matematis Siswa Melalui Pembelajaran Kooperatif Tipe TGT berbantuan alat peraga pada mata pelajaran matematika di kelas VI SD Methodist-12 Medan Tahun Ajaran 2014: Unimed; 2015.

16. Hanissa M, Nur H, Waryana W. Efektivitas Penggunaan Media Leaflet dan Vidio Terhadap Pengetahuan Tentang Pedoman Gizi Seimbang Pada Siswa SMP Negeri 5 Yogyakarta: Poltekkes Kemenkes Yogyakarta; 2018.

17. Nielsen L, Riddle M, King JW, Aklin WM, Chen W, Clark D, et al. The NIH Science of Behavior Change Program: Transforming the science through a focus on mechanisms of change. Behaviour Research and Therapy. 2018;101:3-11.

18. Ririanty M. Komunikasi Kesehatan Program Family Folder dalam Penanggulangan TB Ditinjau dari Teori PRECEDE-PROCEED.

IKESMA. 2017;10(2).
19. Kok G, Schaalma H, Ruiter RA, Van Empelen P, Brug J. Intervention mapping: protocol for applying health psychology theory to prevention programmes. Journal of health psychology. 2004;9(1):85-98.

20. Santoso B S, Erni Mardiati, Irmanita Wiradona. The Effect of Dental Health Education Methods through teacher training to the behaviors of the teacheers and Dental Hygiene of Children with Intellectual Disability. jmscr. 2018;6(5):952-6.

21. Kunto E, Hariyanto T, Ardiyani VM. Hubungan Pola Kebiasaan mendengarkan musik dengan prestasi belajar mahasiswa program studi ilmu keperawatan universitas tribhuwana tunggadewi Malang Nursing News: Jurnal Ilmiah Mahasiswa Keperawatan. 2017;2(1).

22. Ganss C, Schlueter N, Preiss S, Klimek J. Tooth brushing habits in uninstructed adults - frequency, technique, duration and force. Clinical oral investigations. 2009;13(2):203.

23. Kurniawan INA, Suara IM, Manuaba IBS. Pengaruh model quantum teaching berbantuan media audio terhadap hasil belajar IPS siswa kelas V semester 1 SD Gugus 7 Sukawati, Kabupaten Gianyar Tahun Ajaran 2013/2014. MIMBAR PGSD Undiksha. 2014;2(1).

24. Sudjana N, Rivai A. Media pengajaran. Bandung: Sinar Baru Algensindo. 2002 